\title{
Оптимізація процесу фізичної реабілітації пацієнтів з наслідками травм дистальних відділів верхніх кінцівок у післяопераційному періоді
}

\author{
Канюка Є. В., Чернігівська С. А., Забара О. Ю. \\ Науково-дослідний інститут медико-соціальних проблем інвалідності МОЗ України, м. Дніпро, Україна
}

Актуальність. В сучасних умовах соціальні наслідки травм опорно-рухового апарату значні як в економічному, так і в медико-демографічному плані через вагу патології, тривалість реабілітаційного періоду, високу частоту виходу на інвалідність та значні витрати на лікування. За даними вітчизняних дослідників (ІпатовА.В. та співавт., 2015), ушкодження верхньої кінцівки посідають друге місце серед травм органів опори та руху, що становить 76,3\%, при цьому в 31-48\% випадків вони призводять до стійкої втрати працездатності.

Мета дослідження: удосконалення та підвищення ефективності засобів фізичної реабілітації пацієнтів 3 наслідками травм дистальних відділів верхніх кінцівок у післяопераційному періоді.

Методи дослідження: психологічне тестування, гоніометрія.

Результати дослідження та їх обговорення. В ході роботи обгрунтована комплексна методика лікувальної фізкультури (ЛФК) у пацієнтів 3 наслідками травм дистальних відділів верхніх кінцівок у післяопераційному періоді, яка включає диференційоване застосування лікувальної гімнастики залежно від зони ураження дистальних відділів верхньої кінцівки, визначення клініко-морфологічних критеріїв початку та принципів дозування раннього функціонального навантаження, періоду дозованої мобілізації та методики колового комбінованого навантаження, що сприяє поліпшенню ефективності лікування, скороченню терміну непрацездатності та попередженню ускладнень.

Зазначимо, що розроблена методика дозованої (конторольованої) мобілізації застосовувалась для профілактики розривів сухожилкового шва при сильному навантаженні на травмований сегмент кінцівки, $з$ одного боку, та для запобігання формування адгезій і спайок у прооперованій ділянці сухожилків - 3 іншого. На протязі першого тижня після оперативного втручання на час заняття накладалась долонна шина, яка обмежувала згинання пальця в дистальному між- фаланговому (ДМФ) суглобі більше ніж на 20 , на другому тижні допустиму амплітуду рухів збільшували до $40^{\circ}$, а 3 третього тижня здійснювалась лише іммобілізація ДМФ суглоба на період сну. Заняття проводились 4-6 разів на протязі дня тривалістю до 15 хвилин. У проміжках часу між заняттями ДМФ суглоб іммобілізували за допомогою шини в положенні повного розгинання.

Зазначимо, що коловий метод тренування це організаційно-методична форма роботи, яка передбачає послідовне виконання спеціально підібраного комплексу фізичних вправ для розвитку, вдосконалення та відновлення фізичних якостей. Принципом колового тренування є почергове дозоване виконання комплексу із 5-10 вправ (станцій), тренувальний вплив яких спрямований на розвиток конкретної рухової якості чи певних функціональних систем організму. Тренувальне завдання складається із 2-4-разового повторення певного комплексу за точно визначений час.

Застосування запропонованої методики ЛФК показало більшу ефективність щодо відновлення функціонального стану верхньої кінцівки порівняно зі стандартними заходами. В основній підгрупі амплітуда рухів у п’ястково-фалангових суглобах перевищувала показники контрольної підгрупи на $21,3 \%$, у проксимальних міжфалангових суглобах - на 25,4\%, у променево-зап'ястковому суглобі - на 36,9\% $(\mathrm{p}<0,05)$.

Після проведеного лікування показники “важливість" та “задоволення" були достовірно вищі в основній підгрупі (35,6 \pm 0,2 та відповідно $33,5 \pm 0,4$ балів), порівняно 3 показниками контрольної підгрупи, де вони становили $34,4 \pm 0,4$ та 26,9 $\pm 0,9$ балів $(\mathrm{p}<0,05)$.

Отже, запропонована вдосконалена методика фізичної реабілітації пацієнтів 3 наслідками травм дистальних відділів верхніх кінцівок у післяопераційному періоді сприяла ефективному відновленню функцій травмованих кінцівок, тим самим покращуючи якість життя пацієнтів. 